УДК 616.31-002-022.6-636-08

(CDOI

(С). О. Жизномирська, О. М. Слаба, Л. Ю. Мінько

Львівський національний медичний університет імені Данила Галицького

\title{
Клінічні аспекти, комплексна терапія та профілактика гострого герпетичного стоматиту (випадок із практики)
}

\begin{abstract}
Резюме. Герпетична інфекція, зумовлена вірусом простого герпесу (HSV), є одним із найбільш поширених вірусних захворювань людини. Згідно 3 даними аналізу літератури, частіше спостерігають у дітей. Універсальний тропізм HSV до тканин ендотеліального походження спричиняє значний поліморфізм клінічних проявів вірусної інфекції, що призводить до селективного трактування «вузькими» спеціалістами герпетичної хвороби та значно звужує погляд на глобальну проблему. Мета - проведення огляду наукової літератури та висвітлення ролі вірусів із родини Herpesviridae у запуску патогенетичних механізмів виникнення та перебігу гострого герпетичного стоматиту (ГГС), діагностика й комплексна терапія, профілактика рецидивів гострого герпетичного стоматиту в дорослого пацієнта. Проаналізовано джерела вітчизняної та зарубіжної літератури, пов’язаної із тематикою ролі вірусів герпес-групи у виникненні та перебігу ГГС. Представлено клінічний випадок ГГС у дорослого та міждисциплінарний підхід у тактиці лікування та профілактиці рецидивів. На основі ретроспективного аналізу наукових джерел показано, що віруси герпес-групи виступають етіологічним чинником при ГГС та можуть при неадекватному лікуванні переходити в хронічну форму та викликати ураження органів і систем організму. На прикладі клінічного випадку показано необхідність міждисциплінарного підходу в лікуванні ГГС та профілактики його рецидиву. Перебіг гострого герпетичного стоматиту середньотяжкої форми, окрім місцевого стоматологічного лікування, вимагає додаткової співпраці з лікарями-інфекціоністами для здійснення загальної та дезінтоксикаційної терапії захворювання, що дозволяє попередити хронізацію герпетичної інфекції. Герпес-вірусні інфекції становлять провідну медико-соціальну проблему й набувають загальнодержавного значення в Україні. Тому, зростає відповідальність лікаря-стоматолога за ранню діагностику та своєчасне раціональне лікування проявів герпесу на шкірі та слизових оболонках щелепно-лицевої ділянки.
\end{abstract}

Ключові слова: гострий герпетичний стоматит, вірус простого герпесу (HSV), афта, міждисциплінарний підхід, лікування, профілактика.

\section{О. О. Жизномырска, О. М. Слаба, Л. Ю. Минько}

Львовский национальный медицинский университет имени Данила Галицкого

\section{Клинические аспекты, комплексная терапия и профилакти- ка острого герпетического стоматита (случай из практики)}

Резюме. Герпетическая инфекция, обусловленная вирусом простого герпеса (HSV), является одной из наиболее распространенных вирусных заболеваний человека. Согласно данным анализа литературы, чаще наблюдается у детей. Универсальный тропизм HSV к тканям эндотелиального происхождения вызывает значительный полиморфизм клинических проявлений вирусной инфекции, что приводит к селективной трактовки "узкими» специалистами герпетической болезни и значительно сужает взгляд на глобальную проблему. Цель - проведение обзора научной литературы и освещение роли вирусов из семьи Herpesviridae в запуске патогенетических механизмов возникновения и течения острого герпетического стоматита (ОГС), диагностика и комплексная терапия, профилактика рецидивов острого герпетического стоматита у взрослого пациента. Проанализированы источники отечественной и зарубежной литературы, связанной с тематикой роли вирусов гер- 
песа в возникновении и течении ОГС. Представлены клинический случай ОГС у взрослого и междисциплинарный подход в тактике лечения и профилактике рецидивов. Результаты и обсуждение. На основе ретроспективного анализа научных источников показано, что вирусы герпеса группы выступают этиологическим фактором при ГГС и могут при неадекватном лечении переходить в хроническую форму и вызвать поражение органов и систем организма. На примере клинического случая показана необходимость междисциплинарного подхода в лечении ОГС и профилактики его рецидива. Течение острого герпетического стоматита среднетяжелой формы, кроме местного стоматологического лечения, требует дополнительного сотрудничества с врачами-инфекционистами для осуществления общей и дезинтоксикационной терапии заболевания, что позволяет предупредить хронизацию герпетической инфекции. Герпес-вирусные инфекции составляют ведущую медико-социальную проблему и приобретают общегосударственного значения в Украине. Поэтому возрастает ответственность врача-стоматолога за раннюю диагностику и своевременное рациональное лечение проявлений герпеса на коже и слизистых оболочках челюстно-лицевой области.

Ключевые слова: острый герпетический стоматит, вирус простого герпеса (HSV), афта, междисциплинарный подход, лечение, профилактика.

\section{O. O. Zhyznomyrska, O. M. Slaba, L.Yu. Minko}

Lviv National Medical University by Danylo Halytsky

\section{Clinical aspects, complex therapy and prevention of acute Herpetic stomatitis (clinical case)}

Summary. Herpetic infection caused by the herpes simplex virus (HSV), is one of the most common human viral diseases. According to the literature analysis, it is more common in children. Universal HSV tropism to tissues of the endothelial origin causes considerable polymorphism of clinical manifestations of viral infection that leads to selective interpretation of herpetic disease by "narrow" specialists and significantly reduces the view of the global problem.

Aim - to review scientific literature and to highlight the role of viruses in the family Herpesviridae running with pathogenetic mechanisms and course of acute Herpetic stomatitis, diagnostics and complex therapy, prevention of the relapse of acute Herpetic stomatitis in adults.

Materials and methods: sources of national and foreign literature related to the subject of Herpes virus in the occurrence and progression of acute Herpetic stomatitis have been analyzed. Clinical case of acute Herpetic stomatitis in an adult and interdisciplinary approach of treatment and prevention of relapses are presented. Results and discussions: Based on a retrospective analysis of scientific sources, it is shown that the groups of herpes viruses act as an etiological factor of acute Herpetic stomatitis and can proceed in chronic form and cause diseasing of organs and body systems if it is not treated properly. Necessity of interdisciplinary approach in treating acute Herpetic stomatitis and prevention of its relapses is shown in the end of clinical case.

Conclusions: course of acute Herpetic stomatitis of medium-severe form, in addition to local dental treatment requires additional cooperation with infectious diseases doctors to perform general detoxification therapy of disease, that can prevent chronic herpes infection. Herpes virus infections are the leading health and social problem and become of national importance in Ukraine. That's why dental's responsibility for early diagnosing and timely efficient treatment of herpes manifestations on the skin and mucous membranes of the maxillofacial area is being increased.

Key words: acute Herpetic stomatitis, the herpes simplex virus (HSV), aphtha, interdisciplinary approach, treatment, prevention.

Вступ. У даний час надзвичайно часто зустрічаються захворювання, які спричиняються вірусом простого герпесу, що пояснюється не тільки широкою поширеністю вірусу, але й особливостями становлення імунної системи в організмі. Одна третина населення земної кулі уражена герпетичною інфекцією і більше по- 
ловини таких хворих за рік переносять декілька атак інфекції, у тому числі часто 3 проявами в порожнині рота.

Уперше на роль вірусу простого герпесу при захворюваннях слизової оболонки порожнини рота вказав ще на початку XX ст. Н. Ф. Філатов (1902). Він припустив можливу герпетичну природу самого поширення гострого афтозного стоматиту. Ці докази були отримані пізніше, коли в епітеліальних клітинах уражених ділянок слизової оболонки порожнини рота стали виявляти антигени вірусу простого герпесу.

За Міжнародною статистичною класифікацією хвороб і проблем, пов'язаних зі здоров'ям, останнього десятого перегляду (МКХ-10, Женева, 1995), це захворювання реєструються як гострий герпетичний стоматит, що займає не тільки перше місце серед усіх уражень слизової оболонки порожнини рота, але і входить у лідируючу групу серед усієї інфекційної патології людини. Тільки у США щороку реєструються 98 млн випадків лабіального герпесу. Вважають, що близько 90 \% населення Землі інфіковані одним або кількома типами вірусу герпесу, а від рецидивних форм хвороби страждає від 2 до 12 \% населення. За кількістю госпіталізованих у стаціонари різного профілю герпетична інфекція поступається лише грипу та іншим гострим респіраторним вірусним інфекціям разом взятих. Встановлення справжнього рівня захворюваності на герпетичну інфекцію в нашій країні залишається складним, це пов'язано $з$ відсутністю обов'язкової реєстрації захворювань, спричинених вірусом простого герпесу [7, 8].

На сьогодні відомо більш ніж 100 герпес-вірусів, проте тільки 8 з них здатні викликати захворювання у людини [5]. До сімейства герпес-вірусів належать: вірус простого герпесу 1 і 2 типів (HSV-1, HSV-2), вірус вітряної віспи й оперізувального лишаю (VZV), вірус Ештейна-Барр (EBV), цитомегаловірус (CMV), віруси герпесу людини типів - 6, 7, 8 (HHV-6, HHV-7, HHV-8). За даними ВОО3, одним або декількома герпес-вірусами інфіковано від 90 до 100 \% дорослих та дітей. Віруси герпесу здатні викликати ураження різних органів і систем [2].
Особливістю біологічних циклів збудників герпетичної інфекції - викликати латентні та персистентні інфекції. Широке застосування імунобіологічних методів упродовж останніх років підвищило вірогідність у виявленні вірусу герпесу, втручання якого у процес апоптозу через вірусіндуковану модуляцію визначає його майбутню цитопатичність, інтенсивність та низьку ефективність імунних реакцій, і як наслідок, клінічний вияв інфекційного процесу. Вважають, що саме віруси герпесу несуть відповідальність за значну частку інфекційних хвороб людини. Це зумовлено як великим розмаїттям шляхів передачі збудників цієї групи, так і можливістю пошкоджувати практично усі органи і системи людини завдяки здатності реплікуватися у всіх клітинах організму: епітеліальних і нервових клітинах, ендотелії, макрофагах, фібробластах, моноцитах, лейкоцитах тощо [1, 5].

Термін «герпетичні інфекції» об'єднує між собою захворювання, перебіг яких характеризується поодинокими або множинними(згрупованими)везикулярними висипаннями величиною 1-4 мм на шкірі i/або слизових оболонках на набряклоеритематозній основі, на тлі ураження внутрішніх органів. Простий герпес - широко поширене інфекційне захворювання шкіри та слизових оболонок, яке виникає в результаті інфікування вірусами простого герпесу 1-2-антигенних типів, що належать до сімейства Herpesviridae, i характеризується різноманіттям клінічних проявів, хронічним перебігом із тенденцією до прогресування. HSV-1 спричиняє, як правило, ураження слизової оболонки порожнини рота, носоглотки, губ, зберігається у чутливих гангліях трійчастого нерва (в гасеровому вузлі) та інших черепно-мозкових нервів. HSV-2 спричиняє ураження слизових геніталій тощо, персистує в гангліях попериковокрижового відділу хребта.

Герпетична інфекція має 5 періодів розвитку: інкубаційний, продромальний, розпалу хвороби, згасання та клінічного одужання. Інкубаційний період триває від 2 до 17 днів. Виникненню хвороби сприяє травма покривних тканин. Після про- 
никнення інфекційного агента в організм людини він починає розмножуватись у клітинах місцевих тканин і прилеглих лімфатичних вузлах.

Універсальний тропізм HSV до тканин ендотеліального походження спричиняє значний поліморфізм клінічних проявів вірусної інфекції (стоматити, гастрит, виразка шлунку або дванадцятипалої кишки, ураження очей тощо), що призводить до селективного трактування "вузькими» спеціалістами герпетичної хвороби та значно звужує погляд на глобальну проблему. Беручи до уваги, що віруси герпесу володіють тропністю до різних органів та систем, здатні спровокувати або ускладнювати перебіг різних соматичних патологічних станів (гепатитів, панкреатиту тощо) [1].

Часто перші прояви гострої герпетичної інфекції проявляються на слизовій оболонці порожнини рота. Характерним елементом ураження якої є афта, яка виникає на тлі катарального запалення. Прояви гострого герпетичного стоматиту та гінгівостоматиту типові для ураження слизових оболонок. Дана форма хвороби може перебігати у вигляді везикулярноерозивного гінгівіту, виразкового стоматиту, виразково-некротичного стоматиту [3, 4].

Тому первинну консультацію 3 приводу цього захворювання надає лікарстоматолог. За кількістю елементів уражень та формою тяжкості захворювання виникає необхідність визначення потреби в суміжній консультації з лікаремінфекціоністом.

Метою дослідження стало проведення огляду наукової літератури та висвітлення ролі вірусів із родини Herpesviridae у запуску патогенетичних механізмів виникнення та перебігу гострого герпетичного стоматиту (ГГС), діагностика й комплексна терапія, профілактика рецидивів гострого герпетичного стоматиту в дорослого пацієнта.

Матеріали і методи. Стоматологічне обстеження пацієнта, який звернувся за консультацією на кафедру терапевтичної стоматології ФПДО. Лабораторні методи обстеження.

Результати досліджень та їх обговорення. На консультацію звернувся хво- рий С., 1987 р. н., зі скаргами на різку болючість під час споживання їжі та рідини, при розмові, ковтанні. 3 анамнезу хвороби: початок захворювання пов'язує 3 проявами загального нездужання, різкого підвищення температури тіла $\left(38-38,5{ }^{\circ} \mathrm{C}\right)$, прояви інтоксикації (головний біль, блідість шкіри, біль у суглобах).

Об’єктивно: слизова оболонка порожнини рота гіперемійована, визначаються множинні ураження слизової у вигляді афт (рис. 1), 3 локалізацією на внутрішній поверхні слизової оболонки губів, язика, щік та мигдалин. Виявлено вогнища ураження шкіри - в ділянці підборіддя (рис. 2). Відзначено збільшення піднижньощелепних та шийних лімфовузлів (лімфаденопатію).

На підставі скарг, анамнезу захворювання та об'єктивних даних зовнішньоротового та внутрішньоротового досліджень поставлено діагноз гострого герпетичного стоматиту середньої тяжкості.

Результати лабораторних методів обстеження: ЗАК (30.07.14 р.) Hb - 155 г/л, Л - 8,4×1012/Л, П/я - 8, с/я - 50, Л - 38; м - 6; ШОЕ - 40 мм/год. ЗАС - без патології. БАК: білірубін заг. - 14,2 мкмоль/л, пр. - 4,7, непр. - 9,5; тимолова проба - 2,7, сеч. - 5,2, креатинін - 91,4 од./л, АлТ - 0,40, лужна фосфатаза - 0,8. Білкові фракції: загальний білок - 74,4 г/л, альбуміни - 15,0, холестерин - 5,5, $\beta$-ліпопротеїди - 46,0.

Хворому призначено комплекс місцевих заходів: для зменшення болю - обробка афт перед споживанням їжі анестезуючим $10 \%$ розчином лідокаїну, при цьому пацієнту рекомендовано наносити спрей попередньо на марлеву турунду, 3 допомогою якої обробляти афти; полокання розчином «Гівалекс» 3-4 рази на день протягом 7 днів із наступним нанесенням «Стоматофіт-А» на елементи ураження (після споживання їжі). Шкіру обличчя у ділянках ушкоджень обробляти преднізолоновою маззю.

Додатково з метою проведення адекватної загальної та дезінтоксикаційної терапії скеровано пацієнта на консультацію до лікаря-інфекціоніста Львівської обласної інфекційної клінічної лікарні для підтвердження встановленого діагнозу та ко- 

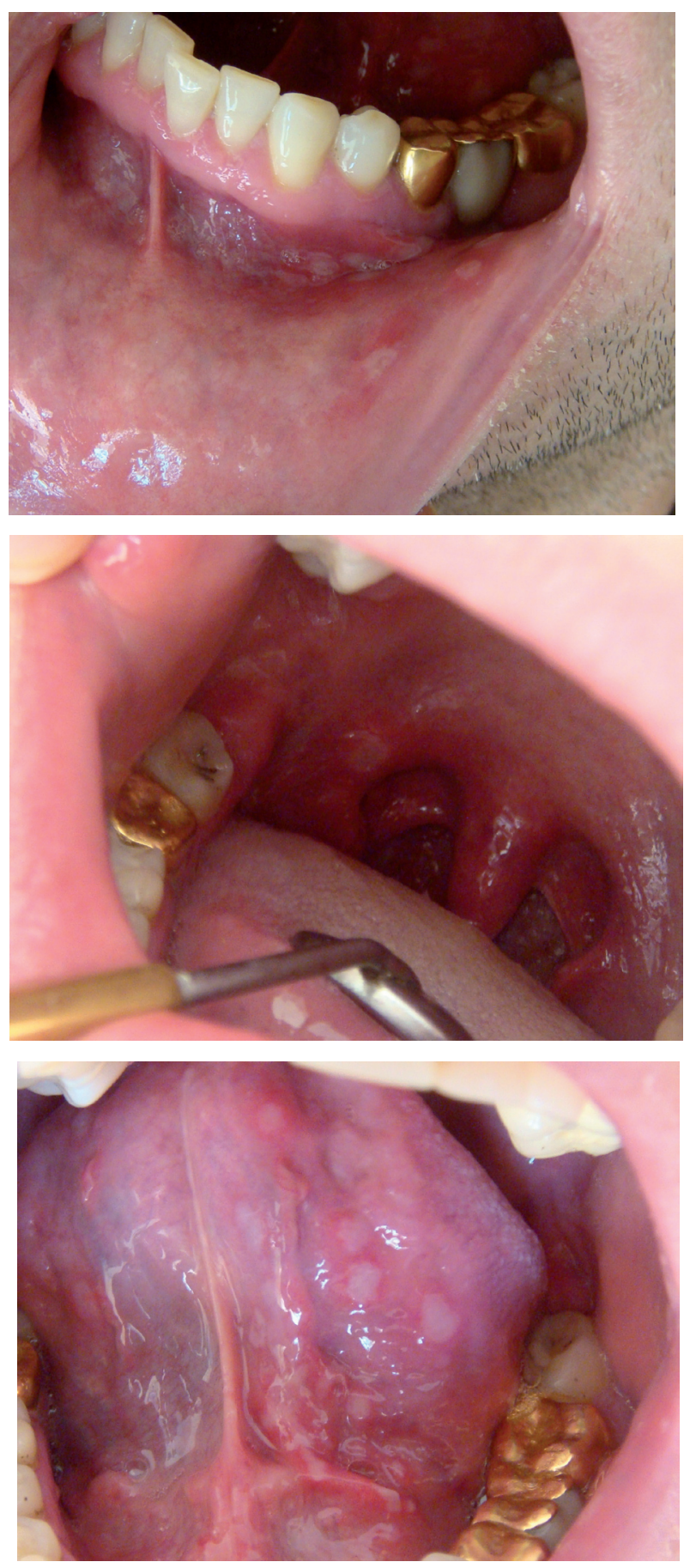

Puc. 1. Множинні афтозні висипання на слизовій оболонці порожнини рота.

рекції загального нездуження пацієнта й призначення відповідної схеми лікування. Пацієнта госпіталізовано 3 діагнозом герпетичної інфекції, гінгівостоматитом, астено-вегетативним синдромом. Стаціонарне лікування включало призначення препаратів: «Цефоперазон», «Флуконазол», «Вітаксон», «Преднізолон», «Тріттіко», дезінтоксикаційну терапію, дієту та

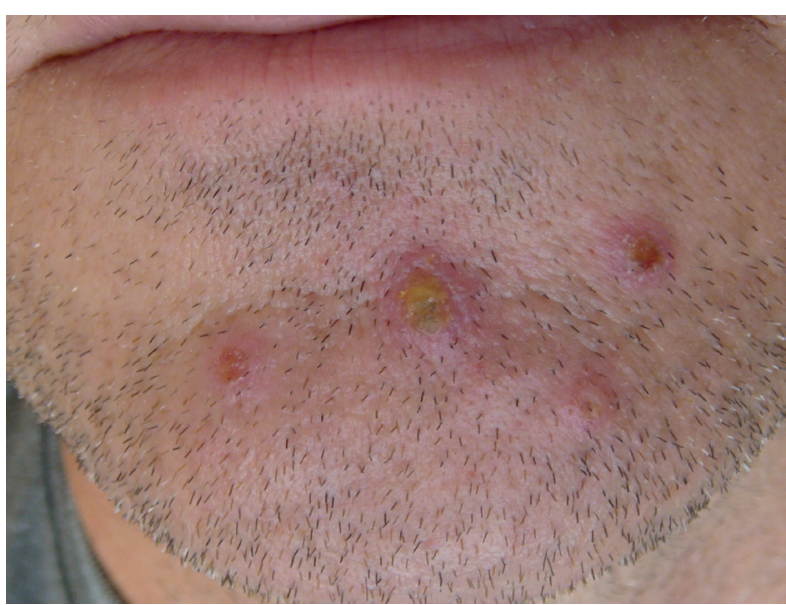

Puc. 2. Елементи ураження на шкірі обличчя пацієнта.

вітамінотерапію. Пацієнта виписано на 8-й день після поліпшення загального стану. Афтозних уражень при повторному візиті після стаціонарного лікування не виявлено.

Для запобігання рецидиву вірусної інфекції курс лікування проводили протефлазидом 2 рази на рік. Дозування призначали згідно з базовою схемою та відповідно до віку пацієнта. При повторних візитах через 6, 12 та 18 місяців рецидивів хвороби не спостерігали (рис. 3).

Висновки. 1. Перебіг гострого герпетичного стоматиту тяжкої форми, окрім місцевого стоматологічного лікування, вимагає додаткової співпраці з лікарямиінфекціоністами, що дозволяє провести адекватну загальну та дезінтоксикаційну терапію захворювання.

2. Застосування профілактичної противірусної терапії дозволяє попередити хронізацію герпетичної інфекції.

3. Герпес-вірусні інфекції становлять провідну медико-соціальну проблему в економічно-розвинутих країнах вже протягом останніх двадцяти років й набувають загальнодержавного значення в Україні. Тому зростає відповідальність лікаря-стоматолога за раннє виявлення, діагностику та своєчасне раціональне лікування проявів герпесу на шкірі та слизових оболонках щелепно-лицевої ділянки.

Перспективи подальших досліджень. Збільшення частоти виникнення та різних форм клінічних проявів гострої герпетичної інфекції на СОПР та шкірі 

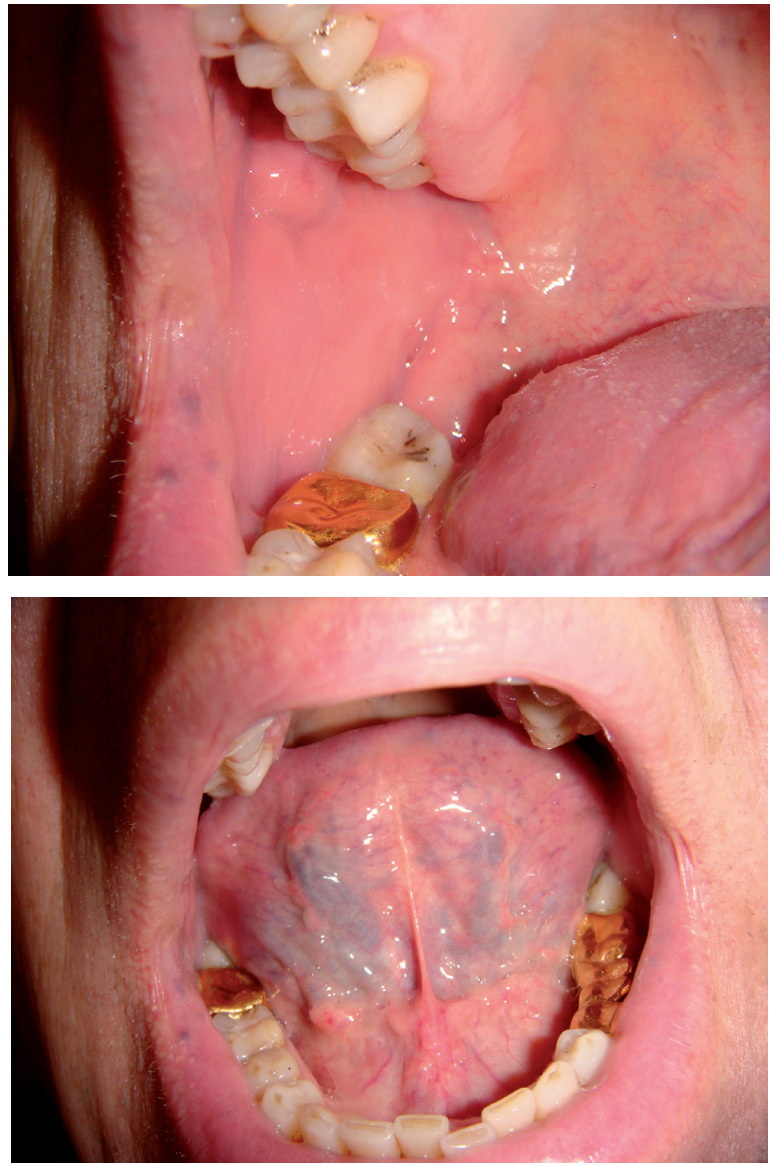
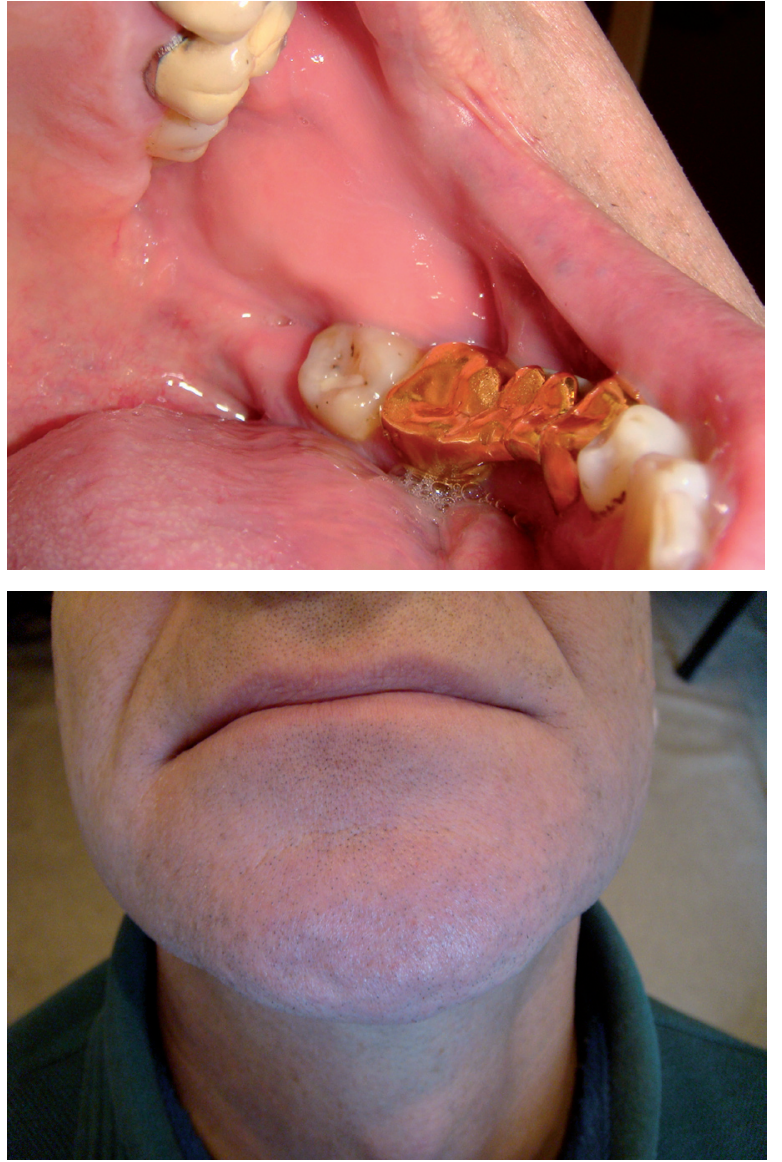

Puc. 3. Стан пацієнта після проведеного комплексного лікування.

обличчя може стати підгрунтям науковопрактичних досліджень, розробки ефек- тивних методів лікування та профілактики пацієнтів із даною нозологією.

\section{Список літератури}

1. Абрагамович О. О. Роль вірусів герпес-групи у виникненні та перебігу дифузних уражень печінки, принципи їх лікування / О. О. Абрагамович, 3. М. Амброзевич, М. О. Абрагамович // AML. 2013. - № 3. - С. 57-66.

2. Волосовець Т. Н. Сучасні терапевтичні підходи до лікування гострого герпетичного стоматиту у дітей / Т. Н. Волосовець // Педіатрія, акушерство та гінекологія. - 2007. - № 4. - С. 119-120.

3. Волосовець Т. М. Визначення вірусів сімейства Herpesviridae у зразках тканин пародонта та дослідження їх імунологічних показників у осіб із запальними та дистрофічно-запальними захворюваннями тканин пародонта, асоційованими із персистувальною герпес-вірусною інфекцією / T. М. Волосовець // Журнал клінічних та експериментальних медичних досліджень. - 2014. - Т. 2, № 1. - С. 80-87.

4. Герпетична інфекція на слизовій оболонці порожнини рота та шкірі обличчя: частота, структура і клінічні прояви / К. Є. Іщейкін, С. О. Білоконь, Л. Г. Павленко, Н. П. Білоконь // Вісник проблем біології та медицини. - Вип. 3, т. 3, № 89. - 2011. - С. 69-89.
5. Попова О. I. Герпетична інфекція як провідна медико-соціальна проблема / О. I. Попова // Сoвременная стоматология. - 2013. - № 2. - С. 48-50. Acute primary herpetic gingivostomatitis [Електронний ресурс] / R. P. Mohan, S. Verma, U. Singh, N. Agarwal // BMJ Case Rep. -2013. - Режим доступу до ресурсу: http://www.ncbi.nlm.nih.gov/ pubmed/23839615.

6. Annie Kitty George. Acute Herpetic Gingivostomatitis Associated with Herpes Simplex Virus 2: Report of a Case [Електронний ресурс] / Annie Kitty George, Sukumaran Anil // J. of International Oral Health. - 2014. - Режим доступу до ресурсу: http:// www.ncbi.nlm.nih.gov/pmc/articles/PMC4109238/ pdf/JIOH-06-03-099.pdf.

7. Evolutionary Origins of Human Herpes Simplex Viruses 1 and 2 [Електронний ресурс] / O. Joel Wertheim, D. Martin Smith, M. Davey Smith [et al.] // Mol. Biol. Evol. - 2014. - Режим доступу до реcypcy: http://www.ncbi.nlm.nih.gov/pmc/articles/ PMC4137711/pdf/msu185.pdf.

Отримано 03.02.16 